\title{
Analogical Reasoning in Statutory Law
}

\section{Maciej Koszowski*}

Jan Długosz University, Częstochowa, Poland

*Corresponding author: Maciej Koszowski, Assistant Professor, Jan Długosz University, Częstochowa, Poland, Tel: 0048343783164; E-mail: negotium@op.pl

Received date: February 13, 2017; Accepted date: March 06, 2017; Published date: March 10, 2017

Copyright: (C) 2017 Koszowski M. This is an open-access article distributed under the terms of the Creative Commons Attribution License, which permits unrestricted use, distribution, and reproduction in any medium, provided the original author and source are credited.

\begin{abstract}
This article addresses the scope of the potential applications of an analogical argument in the domain of statutory law. The author thus shows how analogy leads to the liquidation of different sorts of legal gaps: extra legem, intra legem, contra legem, technical, logical and constructional. He also highlights the role which analogy can play as a universal method of applying particular statutory provisions in concrete cases, the way of coping with obsolete statutes with the help of an analogical inference, or the clarification of the wordings of statutory rules by recourse to reasoning from similarity. In the article, allowance has also been made for the linking of an analogical pattern of thinking with specific legislative techniques such as the 'ejusdem generis canon of construction' and 'pertinent application of statutory law.' In addition, the analogical basis of comparative arguments, the possibility of expanding the domain of statutory law with the use of analogy at the expense of the room reserved for customary and precedential law as well as special forms of analogical reasoning: argumentum a fortiori and analogia iuris have been discussed.
\end{abstract}

Keywords: $\quad$ Analogy; Analogical; Reason; Reasoning; Statute; Statutory; Gaps; Legal; Law; Applying; Application; Scope; Pertinent; Notions; Conflicts; Rules; Lacuna; Iuris; Legis; A Fortiori; Ejusdem Generis

\section{Introduction}

Analogical reasoning is commonly associated with precedential law, the core idea of which, exactly like analogy itself, consists in proceeding from the particular to the particular, from one case to another. The province of precedential law may - without exaggeration - thus be considered the natural home of analogical reasoning [1]. Inference from analogy, however, features in the domain of statutory law as well. As MacCormick points out, "argument from analogy is by no means uncommon or unimportant in the application and interpretation of statutes" [2]. Incidentally, an interesting comparison is also made by Bergholz and Peczenik, who compare precedential law to a casuistic statute, by stating that: "In interpreting precedents, use is made of a number of reasons which in part resemble argument by analogy in statutory interpretation. Practice as a source of the law resembles a markedly casuistic statute, the application of which calls for conclusion by analogy on a large scale" [3].

In this paper, I subscribe to the aforementioned thesis, endeavouring to highlight all the possible usages of analogical reasoning in the area of statutory law. Analogy employed here - apart from being preceded by the adjective statutory - is sometimes called "argumentum a simile (a simili)" [4-21], i.e., an argument from similarity (or an inference based upon similarity), argument/reasoning "a pari" [22,23], "argumentum a similibus ad similia" [24] or "argumentum (inference) per analogiam" $[7,8,16]$. Moreover, it can also be conflated with an argument ab exemplo (i.e., an argument from paradigmatic examples) [16]. This does not, however, mean that some of these names, as "argumentum a simili, cannot be used with reference to analogy in precedential law [14].

\section{Filling the Gaps}

In the province of statutory law, analogical reasoning is recognized above all as a means for the liquidation of the so-called legal gaps (lacunas), which - incidentally - can be of a different, and sometimes quite sophisticated and sublime, sort [5,7,11,13,25-44].

\section{Extra legem gap}

According to the orthodox theory, a legal gap occurs whenever there is no statutory rule that can be applied to the case at hand, although it is socially desirable to have such a rule and the case at hand being provided for.

This type of gap is commonly termed an extra legem or praeter legem gap [5,10,11,26,27,30,35,45], or "extrinsic gap" [46], or simply "statutory gap" [42]. It stands also in close affinity to the division into regulated cases/disputes and unregulated ones [33] alias to the distinction between provided cases/disputes and unprovided ones (the occurrence of the so-called "casus omissus") [40,44]. Sometimes gaps of this type may also be called: "an insufficiency gap" [38] and "inconsistency or evolutionary gap" [30]. (An "inconsistency gap" is linked with the situation in which the case is unregulated by the law although the need of consistency within legal system calls for this case being provided for, while an "evolutionary gap" pertains to the setting in which a changed social environment has yielded a new factual configuration of previously unknown shape that should be regulated by the law yet, due to its unpredictability at the time of enactment of a pertinent statute, it is not [30].) Additionally, in certain circumstances, it can be linked with the phenomenon of undergenerality of the language that is implemented in the wording of a statute in relation to the purpose of this statute [40]. That kind of gap happens also to be tagged as: "axiological" ("evaluative") or even "seeming" or "false" gap $[4,6,7,10,13,34,46,47]$. The question whether legal gaps are evaluative (value-laden) or not is, however, sometimes posed in relation to all type of gaps, not only extra legem ones $[28,29]$. (As an aside, at this juncture, it might be also worth noting that considered from a slightly 
different angle, gaps consisting in the lack of legal regulation for a given sort of cases may be divided into subjective and objective ones. Thus, according to Bobbio, the former results from "inadequate legislative regulation", whereas the letter results from "the new formation of the relationship and of an institution" [48].

The filling of extra legem gaps by resorting to analogical reasoning consists in principle in finding a statutory rule that embraces cases that are similar to the case at hand and then - although this case does not fall under its coverage - applying the so-selected rule to the case at hand $[4,5,30,36,38,40,49,50]$. Accordingly, Summers et al. point out that "when a case is not provided for or is only at best dimly provided for in statute, the case is to be treated in the same fashion that closely analogues case are treated in the statute" [50]. Wróblewski states that "if the existence of gaps is admitted, the task of court is to fill them by using statutory provisions which regulate essentially similar problems or cases" [36]. Peczenik et al. maintain that "by virtue of 'analogia legis', a statute should be applied not only to the case covered by its linguistic meaning but also to relevantly similar cases" [38]. And Summers notes that "sometimes a statute will purport to treat a topic exhaustively but an 'unprovided case' will arise. Here the court may treat this case analogously to the way in which 'provided' case is treated in the statute" [40]. (Parenthetically, an extra legem (undergenerality) may be filled by treating instances that literally would be outside the scope of statute as regulated ones also upon another basis than analogical reasoning, for instance, teleological interpretation, which - as Summers remarks - often "will call for little more than characterization and reclassification of instances otherwise outside the statute" [40].

In consequence, in such a setting, an argument from analogy may be said to "extend the force of existing rules beyond their direct range of application" [33]. Such an extension can be justified here by the very requirement of equal treatment, known also as the so-called principle of formal justice, which prescribes that: when in a similar position one should be treated as others are. Having transferred this idea to legal matters, it means the cases that are alike ought to be decided on in the same or similar manner (regardless of their being provided for or not). That requirement/principle is all the more important when combined with the assumption that the events transpiring in the law are universalizable in the sense of their capability of being brought under the general categories (kinds, classes, genera). The filling of extra legem gaps by analogy also has its foundation in the pursuit - in legal practice and theory - of the coherence and completeness [closure] of the legal system [24,50,51]. Thus, for instance, Summers et al. contend that the relatively universal appeal of statutory analogy "is presumably rooted not only in considerations of coherence and unity but also in the ideal of equality before law" [50].

The sort of analogy that is used to fill this kind of gap sometimes takes its own name, then being called: "analogia legis" [4-7,9,10,17-19,20,24,34,38,43-45,49,51-55] or "statutory analogy" $[7,10,45,52,56]$ (Such a meaning of analogia legis, i.e., as reasoning leading to the application of a statutory provision to similar instances that are unprovided for in the statutory law, is, incidentally, said to date back to the end of the $17^{\text {th }}$ century and became almost completely accepted by the $19^{\text {th }}$ century) [49]. One may also - as Nowacki and Jamróz do - use a more precise term here: "analogia extra legem." The latter terminological proposition arises from the fact that the analogy (its conclusion) that liquidates the gap goes here beyond the very "lex" (Eng. Law), by which one should understand valid statutory rules; not to mention the fact that the gap which analogy is used to fill here also has the name "extra legem" $[11,45,49,57,58]$. In German legal theory, statutory analogy (analogia legis) is termed: "Gesetzesanalogie" $[41,52]$.

Although usually perceived as an instance of judicial development [32] or even the creation $[33,49]$ of the law, analogia legis (statutory analogy) is well-known in civil law countries, in time receiving a relatively favorable reception. Its use is, for instance, recognized in: Argentina, France, Germany, Sweden, Finland, Poland and Italy $[4,6,13,33,34,50]$. At the same time, as Summers and Taruffo also point out, this analogy seems far less influential in the UK and USA. Here, an unregulated case may be counted as belonging to the province of common law and as such resolved in the manner typical of that law, i.e., without any necessity or need to refer to some statutory rule that addresses similar case or cases [50].

\section{Technical gap}

Another kind of legal gap that can be filled by reference to analogy consists not in the lack of a single statutory rule, but in the lack of a larger part of statutory law. For instance, this can be the non-existence of some section in a statute (especially when, judging by the structure, table of contents or headings and subheadings, and this section should be included therein). Similarly, the lack of the procedure in which members of a public organ or agency should proceed, make a decision or be appointed testifies to the occurrence of just such a gap. The same applies to the non-existence of rules following which the institution or legal act which is envisaged by law is to be established/issued. The most extreme instance of such a gap seems, however, to be the lack of the whole legal regulation (e.g., statute, regulation, ordinance) that should be adopted in accordance with a statutory or constitutional provision $[35,40,43,46]$.

This kind of gap is called: an "intrinsic gap" $[25,46]$, "technical gap" $[4,6,10,43]$, "constructional gap" $[4,6,9,10,13,34,47,59]$, "gap of passivity" [30], "vertical gap" [28] or "sui generis gap" $[4,5,6,7,10,11,35,45]$. It might also be termed: "instrumental gap", i.e., the gap that makes it impossible to execute the goals of a statue [6]. (Interestingly, Morawski and Opałek as well as Wróblewski distinguish "technical" gaps from "sui generis" gaps. Accordingly, in their view, technical gaps encompass such instances in which the defects of statutes make it impossible to render a legal decision - for example the statute may have set up some institution but it does not provide for any provision referring to the way in which the members of this institution are to be appointed. The gaps "sui generis", in turn, denote the lack of statutory provisions whose enacting/issuing is required by some other statute. This distinction is, moreover, to be of this practical value that in the view of these authors, "sui generis" gap cannot be liquidated by recourse to analogy $[4,5,6,11]$. Also, Pulka understands this differentiation in a very similar manner, in addition adding that "technical" and "sui genereis" gaps constitute two possible forms of the so-called "constructional gap" [10]. A constructional gap is, in turn, defined by Municzewski et al. as a situation when the statutory law envisages the possibility of conducting some 'conventional act', yet it does not comprise any legal regulation as to how this act ought to be done $[13,34,78]$.

To fill such a gap, one looks for statutory provisions or provisions that are to be found in other legal acts (regulations, ordinances, decrees etc.) which - thanks to addressing similar matters or serving similar goals - may constitute a model for supplementing the legal regulation which is lacking. Specifically, the provisions one may pattern may come from the so-called "uniform act", "model act" or "federal 
Page 3 of 10

prototype", particularly as regards the legal system of the USA [40]. In turn, in civil law countries, another part of a legal act is usually used for that purpose, particularly a legal code, and regulates related matters in other branches of law. For instance, in this manner some provisions of the code of civil procedure can be applied per analogiam to the criminal proceedings in matters which, despite being vital, are unregulated by the code of criminal procedure.

Analogy which leads to the closure of this kind of gap might be called: analogia intra legem (analogy within the law) [11]. As an aside, one may note that "constructional gap" is sometimes counted as an actual (real) gap - i.e., gap which is not 'evaluative' or only 'seeming' and hence the possibility of its filling by recourse to analogical reasoning remains beyond doubt [13].

\section{Contra legem gaps}

The next kind of legal gap that can be liquidated by recourse to analogical reasoning is linked to the situation in which, although the case at hand is undoubtedly within the scope of the application of a given statutory rule, one prefers not to apply this rule to the case at hand, applying it instead to a rule under whose scope it does not fall at all. As MacCormick states "What is true is that a system of enacted positive law may be enacted in terms which are of such considerable generality that the application of a given enacted rule to a particular dispute situation may appear to unjust, unjust because the categories envisaged in the rule are insufficiently subtle. In such a circumstances it is obvious enough that there are good reasons for not applying the rule literally to the instant case, and that an exception ought to be made" [60]. "We also require that rules should not be rigidly applied by a thoughtless bureaucracy. If an exception is reasonably judged to be a relevantly different enough case to fairly qualify as an exceptional case, then we require that the rule should be broken" [60]. The reason for doing so lies here in the presupposition that this latter rule is more adequate for the case at hand, especially because it addresses cases that are more similar to those at hand than the ones usually handled by the rule which is directly applicable to this case $[30,35,49]$.

Gaps of this kind are called an "axiological gap" [10,38], since the ascertainment of its occurrence is anchored in evaluation (is valueladen), or a "contra legem gap", since it is aimed against the operating law, i.e., contradicts an already existing valid rule the case at hand falls under $[5,10,11,27,30,45]$.

An analogy which is employed to fill a gap of this sort is counted as "analogia intra legem", since the cases it affects were previously regulated by law and remain so after it has been used $[11,49,58]$, or "analogia contra legem" [49]. By referring to the rule which regulates cases similar to the case at hand, one resolves not only the case which has already been provided for but also those contrary to the legal consequence which - at least prima facia - the law prescribes for it. Such an analogy is also sometimes numbered amongst the so-called systemic arguments [42]. However, this does not seem accurate.

It is particularly noteworthy that the aforementioned kind of analogy is even more creative than analogia extra legem which helps with liquidating extra legem gaps, for not only does it expand the already existing laws but it also corrects and improves them if they are not optimal or just. This does not, however, mean that the concept of "contra legem" does not draw criticism. It is based upon the charge that the admittance of such gaps would diminish reverence for law, threaten the legal order and violate the very requirement that everyone is required to abide by the law [27].

\section{Extending Statutory Provisions at the Expense of Precedential and Customary Law}

In Anglo-Saxon legal systems, analogy may also be used in order to diminish the sphere of the so-called precedential law (case law, common law). That is, the statutory rule can be extended by analogy at the expense of the existing or will-to-be judicial precedent(s). The same, mutatis mutandis, applies to truncating the range of customary law by analogy.

In general, such an extension can be done in a twofold manner. First, a case hitherto controlled by a judicial precedent may be regarded as similar to cases falling under a particular statutory provision with the effect of having applied such a provision to this case despite its scope of application not embracing it. Second, when there is no constraining precedent for the case at hand, one may seek a solution not among other precedential cases that resemble the case at hand, but among the statutory provisions which regulate cases similar to it $[39,40,50,61]$.

The question of whether and when to use an analogy which restricts the current ambit of precedential law seems, however, to be debatable in Anglophone countries [40]. It is also quite plausible that the classifying of a concrete case under those which belong to the domain of precedential law or those which belong to the province of statutory law can prove difficult in practice and hence analogies to precedential cases may be regarded as equally good to those provided for by the statute $[39,40,50]$. Thus, for instance, Cross asserts that: "Whether the courts regard legislation as the equal or superior of judge-made law when it is cited as an analogy upon which to found a decision must be regarded as an open question"... "Legislation should surely only be regarded as the superior of case-law in this respect when there are competing analogies of equal force from each of these sources" [61].

\section{Crystallizing the Meaning of a Statutory Rule (Provision)}

Quite another way of using analogical reasoning in statutory law is connected with the act of comparing two or more statutory provisions (the rules derived from them) in order to establish their appropriate meaning - as Summers et al. point out, "one statue may be construed on analogy to the way another statute is construed" [50] and as Cross notes, "the terms of one statutory provision may be used as the ground of a conclusion concerning the construction of another statutory provision" [61]. The juxtaposition of such provisions enables us to see both or one of them in the light of the other and thus crystallizing or harmonizing their wordings ("the governing idea here is that, if a statutory provision is significantly analogues with similar provisions of other statutes, or code, or another part of the code in which it appears, then, even if this involves significant extension of or departure from ordinary meaning, it may properly be interpreted so as to secure similarity of sense with the analogous provision either considered in themselves or considered in the light of prior judicial interpretations of them") [62]. Such a manoeuvre can be particularly useful when one of the statutory provisions used for comparison is - due to some reason much plainer, more determined or more understandable than the second. Then, the proper meaning of an equivocal word or phrase included in the latter may be ascertained by turning to an identical or similar word or phrase that occurs in the former. Incidentally, in this process, the circumstances of the enactment (the context) of the provisions being compared should also be taken into account and only if these circumstances (contexts) are sufficiently similar will the 
aforementioned fashion of finding the meaning to be well-founded $[30,34,39,40,49,11]$.

Naturally, one can employ analogical reasoning in order to establish the meaning of the wording of a given statutory provision (rule) also through likening the words used in such a provision to identical or similar words from other statutes that have been explained in judgments, especially those among them that have the status of socalled binding or persuasive precedents. In such a setting, argument by analogy does its work in the following manner: "a word should be interpreted in a given way because this will treat similar cases similarly under related statutory provisions" [40], which, albeit, does not impair Cross's warning that "it is fatally easy to adopt some such line of reasoning as the following: the instant case is concerned with the meaning of such and such an expression. That expression was interpreted in such and such a way in a previous case, therefore that interpretation should be applied in the instant case. It is unnecessary to enlarge upon evils of such an approach" [61].

With reference to common law countries, however, it must be noted that a judicial decision which interprets statutory provisions is not considered here as binding with regard to other statutes, even if they involve exactly the same word or phrase. Such judicial interpretations can only be of some guidance, leaving room for other more justified interpretive propositions if they arise [39].

Utilizing analogical reasoning in statutory law in the abovementioned way might be termed interpretive analogy or rule (norm)comparing analogy or even - as Nowacki terms it - "analogia intra legem" $[45,49]$. This usage of analogical inference can also be counted among systemic methods of interpretation (systemic arguments), i.e., the methods that base upon the observation that legal rules operate not in a vacuum as separate entities, but are interconnected with each other, composing a bigger picture $[24,62]$.

\section{Drawing a Comparative Argument}

Analogy also constitutes the basis for the other forms of comparative argument that one may employ in statutory law. To determine the meaning of the provisions of a domestic statue, the interpreter sometimes refers to foreign statutory regulations. The precondition of such a venture is, however, the assumption that first the foreign regulation deals with the same or similar matter as the matter regulated by the domestic law and, second, that the foreign legal system (milieu) resembles the one in which the reference is made [39]. Thus, if the foreign conditions, including cultural, social and political factors, are analogues to those that prevail in the state of the interpreter, comparative arguments based upon foreign statutes will be of some force. If not, however, arguments of this kind seem more or less pointless. The same principle applies to situations in which in order to elucidate the canonical text, one refers not to statutes from other jurisdictions but to the foreign judicial or doctrinal interpretations of them.

The admittance of out-of-jurisdiction statutes and judicial opinions in legal argumentation is, however, not always unquestionable. Such admittance is for instance debatable in the USA [63-65].

\section{Coping with Obsolete Statutes}

One more usage of analogical reasoning in statutory law may be discerned in the following settings. The case at hand falls under an old statute that, despite its obsolescence, is still in force. The new statute addressing the similar subject matter has been enacted, yet it does not make the older one invalid and is not directly applicable to the case at hand. Nonetheless, in lieu of applying a provision from the older statute which the case at hand falls under, a court resolves to base the decision upon the new statute, i.e., its provisions that embrace cases similar to the case at hand, its underlying principles or its spirit (ideas, purposes, leading thoughts). The court may also be enlightened here by the governmental note that was attached to the bill (draft) of the new statute in order to explain the need and reasons for its being subsequently enacted by the legislature. Mutatis mutandis, the same goes for the application of the provision(s) of a new statute which would be directly applicable in the case at hand, but have not come into force at the time of the judicial decision [30].

\section{Application of Statutory Law}

The most controversial is, however, the presence of analogical reasoning in the general process of the application of statutory law. According to this idea, there are obvious (typical) instances which a given statutory rule applies to and whenever the case at hand is not identical to such obvious/typical instances, one has to ascertain whether it is relevantly similar to at least one of them or not. If such a similarity obtains, it means that the statutory rule should be applied to the case at hand as well. The typical/obvious instances of the application of a given statutory rule may have their origin in the intention of the legislator, be cases which have already been qualified by the courts as falling under this rule, be grounded in the common understanding of words used in this rule, or just be those that naturally come to mind $[1,32,39,49,63,66-73]$.

Thus, for instance, Levi announces that: "It is only folklore which holds that a statute if clearly written can be completely unambiguous and applied as intended to a specific case. Fortunately or otherwise, ambiguity is inevitable in both statute and constitution as well as with case law. Hence reasoning by example operates with all three"[66]. Murray et al. note that: "Often the legal rules used in the rule-based reasoning syllogism require explanation and illumination to demonstrate for the reader why your prediction of the outcome is legally sound and likely to occur. Analogical reasoning is used within the rule-based reasoning syllogism to further the overall discussion by showing how the rule itself or elements of the rule are supposed to work by discussing and analogizing to or from certain actual circumstances (cases) where the rule was applied to produce a certain outcome" [63]. Braman points out that: "In statutory construction, for instance, when the "plain language" of a disputed provision is ambiguous, judges often look to previous application of the law, seeking to draw connections and/or distinction between past and pending scenarios. Using analogy in this way helps judges make reasoned decisions about whether or not a particular rule should apply to circumstances giving rise to litigation" [67]. Bankowski et al. elucidate that: "Where the problem is whether or not to qualify a problematic phenomenon as instantiating some statutory term or another, analogy to less problematic instances covered by prior decisions is relevant" [39]. Sunstein makes the observation that: "In hard statutory cases, the issue is sometimes resolved by something like this: We know that the statue applies to case X. We do not know if it applies to case $\mathrm{Y}$. To resolve the issue, we have to decide whether case $\mathrm{Y}$ is relevantly like, or relevantly unlike, case X. We have to think analogically" [68]. And Burton captures this issue in the following manner: "Analogical reasoning may be used to help interpret and apply an enacted rule. The analysis begins with the enacted text. It may help 
Page 5 of 10

to find base points in the context that can be used to reason analogically in a problem case" [69].

The paradigm example of using analogy in the aforementioned way is the ascertainment of the meaning of words occurring in a statute that are vague and value-laden or where the statutory meaning for some other reasons is dependent on judicial assessment/adjustment. According to Alexy et al. a particular term is said to be vague "when there are some subjects that indubitably fall within its scope (positive candidates), some subjects that indubitably do not fall within its scope (negative candidates) and a third class of subjects cannot be said to belong to one or the other with certainty (neutral candidates)". Evaluative openness [being value-laden] characterizes, in turn, those terms which have "but little descriptive contents over and above their evaluative component" and in relation to which the task of the judiciary is "to fill them with descriptive meaning to match as well as possible their evaluative component, a task likely to be performed differently by different judges" - as examples of such terms one may thus invoke: 'good faith', 'reprehensible' or 'sensible reason' [41].

The occurrence of words of that kind is even comprehended in terms of the legal gap, however specific a one. Scholars call it "intra legem" [26,27,35,45] ("inter legem") [5,11,26,27,30] "indeterminacy" [38] or "interpretational" $[26,42]$ gap. As to the latter, Aarnio defines such a gap as the situation "where we cannot say for certain what provision would be applicable to the case at hand" [42]. Although the configuration known under the concept of intra legem gap is qualified as a kind of a legal gap mainly in civil law legal systems, it can be regarded as such in common law legal systems as well. For instance, in relation to the USA, Summers elucidates that "gap in statutory scheme may be said to exist when a statute includes a general clause or other terms which grant discretion to courts or administrators" [40].

The recourse to analogical reasoning in order for liquidation of intra legem gap is widely accepted. However there are also some who oppose such a possibility[11]. The analogy that serves to this aim can be in turn termed: "analogy in interpretation (construing) of the law" or counted as a type of "analogia intra legem", as Wróblewski and Nowacki together with Jamrz do respectively $[45,49]$.

Evidently more far reaching, however, is the thesis that statutory law is always or nearly always applied via an analogical inference. As Weinreb argues, "[f] or both reasons - because words, as symbol with meaning, are general and phenomena, as such, are particular, and because words, however precise, do not fully distinguish phenomena in all their variety - there remains a gap between a rule and its applications that no further statement of the rule or specification of the facts will close completely" [71]. Likewise, Kratochwil contends that "norm-application is never a mere subsumption, but always entails an evaluation on the basis of analogies which are held to be relevant" [77].

The prevailing stance - at least pertaining to civil law legal families - seems, however, that the place of the main method of applying statutory law is taken by legal deduction (especially in the form of the so-called legal syllogism). Nonetheless, when an intra legem gap occurs, the interpreter appears here to be fully entitled to take advantage of analogical reasoning in order to decide whether a given statutory provision (a rule derived from it) should be applied to the case at hand: through the comparison of the facts of the case at hand with typical instances of the application of the provision (rule) which applying to this case is dubious.

\section{Resolving Conflicts between Statutory Rules}

Analogical reasoning may also be of help when one is faced with two or more conflicting statutory provisions (rules one may derive from them).

In general, clashes between statutory rules may be of a different sort. For instance, one statutory provision may impose an obligation or right that excludes the obligation or right envisaged by another statutory provision. One statutory provision may prescribe behaviour whose performance impairs or cancels the effect which results from abiding by another statutory provision, though these provisions do not contradict each other from the logical point of view. As an example, the two following directives might be invoked: open the window while it is closed and close the window when it is open. Finally, one statutory provision, despite not being in overt conflict, pursues goals that are at odds with the goals being ascended by another $[5,10,26,27,33,49,59]$.

The collisions between statutory rules are sometimes regarded as legal gaps. Depending on its kind and terminological convention, this can be a gap of conflict or collision [26,30,35], praxeological (teleological) gap [5,26,27], logical gap [7,13,34,59] or a gap by contradiction [26]. Moreover, in the context of two or more conflicting statutory provisions (rules) one may also encounter the notion of "alternative gap". This name presupposes, however, that one of the conflicting provisions (rules) should be selected and the case at hand is to be decided upon it (the option that these provisions/rules may cancel each other is out) [26]. The aptness of usage of the term gap for denoting the conflict of statutory provisions (rules/norm derived from them) as well as the non-evaluative nature of such a gap are in addition not such that cannot be challenged $[26,29]$.

In order to cope with the above-mentioned gaps, different principles are envisaged that are based mainly upon the hierarchy of legal acts, the time of enactment or the degree of vagueness (concreteness) of the provisions being in conflict $[4,5,9,10-17,19,45,53,58,78]$. Among these principles, however, one may also find such that orders the determination of which of the conflicting statutory provisions (rules) is - in essence - more adequate for the case at hand. In turn it may follow that priority should be given to those rules that are in dissonance with regards to typical or obvious instances of application that are more similar to the facts of the case at hand (albeit respecting the collision of precedential rules) [71]. Moreover, a gap arising from the conflict of statutory provisions (rules) can also be resolved not by rendering an analogy to one of the provisions (rules) which collide with each other but by analogy to yet another statutory provision (rule) that regulates cases similar to the case at hand [26,29]. A lateral question parenthetically - is here whether the colliding rules cancel each other, one of them annuls the other one (the rest) or, despite being in conflict, they still remain in force. Thus Nowacki points out that when the collision of two norms [rules] occurs there are three possibilities: a) the elimination of one of these norms, b) the elimination of both of them, c) keeping both in force and regarding them as valid despite acknowledging their being in conflict [26].

One should note, however, that recourse to analogy in order to fill the gap stemming from the collision of statutory provisions (rule) is usually deemed possible only if other rules of settling conflicts cannot be availed of or turn out to be unsuccessful $[13,26,34]$. 
Page 6 of 10

\section{Untangling the Ejusdem Generis Canon of Statutory Construction}

Another place in which the employment of reasoning via analogy in statutory law can be discerned is the so-called "ejusdem generis canon of statutory construction (interpretation)" [70,71], a canon which may be regarded as a technique of composing canonical texts or construing them.

According to Hunter, the phrase: ejusdem generis means: of the same kind, genus and nature, and when featured in a statute, it takes the form of: " $\mathrm{x}, \mathrm{y}, \mathrm{z}$ or other" [80]. While the terms: $\mathrm{x}, \mathrm{y}$ and $\mathrm{z}$ are precise and specific, the word "other" is by definition of indeterminate nature. Apart from this word, the presence of ejusdem generis may also be inferred from placing some other expression in the statute indicating that next to the instances enumerated also some other expressly unmentioned are at stake. For instance, such statutory expressions could have a form: “ $\cdots$ particularly $\mathrm{x}, \mathrm{y}$ and $\mathrm{z}$ " $[39,40,52,80]$. Reverting to the question of the mediation of analogical reasoning in the ejusdem generis canon of construction, this reasoning may be used in order to determine - upon the similarity discerned between it and these instances - whether the case at hand which is not any $\mathrm{x}, \mathrm{y}, \mathrm{z}$ falls under "other" (belongs to the category which $\mathrm{x}, \mathrm{y}, \mathrm{z}$ are particular examples). That is, one may assume that the word: "other" (category specified by enumeration of its examples) present in ejusdem generis include - at least inter alia - instances that are similar to those which have been explicitly listed on ejusdem generis (eiusdem generis).

Thus Brewer argues that: 'This interpretive norm (the ejusdem generis canon of construction) instructs the interpreter of a series of terms that are either relatively more specific or more precise (or both) followed by a term that is either relatively more specific or more precise (or both) followed by a term that is either more generally or more vague (or both) to read the last term in a series as being "of the same "genus" as the previous, more specific terms. Often, it is exemplary reasoning that interpreter uses to discover the "genus", that is, the category, to which both the series of specific (or precise) terms and the general (or vague) term belong' [70]. Likewise, Levi states that "the specification of particular instances indicates that similar but unmentioned instances are not to be included. But the specification of particular instances, when in addition a word of general category is used, may be the indication that other like instances are also intended; hence the ejusdem generis rule" [66]. Hunter, however, maintains that "the ejusdem generis rule clearly relies on inductive inference" and disagrees thus with Brewer's stance invoked above [80].

Incidentally, the same apply to another known canon of construction, "noscitur a sociis", which can be translated as "a thing known by its associates" [40].

Though ejusdem generis is traditionally associated with common law legal systems, it appears in civil legal systems as well. This mainly concerns the second form invoked above, i.e.,: “..., especially $x, y, z$ ” or even more conspicuously, " $x, y, z$ or the like" [10]. Moreover, statutes, especially those enacted in private law, may be deemed here as often comprising so-called 'typological notions'. Notions of this kind specify a certain set of features that give a picture of a typical object or state. To fall under them, however, a given object or state needs not correspond with all the features enumerated. It suffices that this object/state is merely relevantly similar to its typical (ideal) counterpart. This possibility makes 'typological notions' essentially different from the socalled: 'classifying notions' in case of which a complete fulfilment of all the defining features is required. The 'classifying notions' are thus maintained to be more adequate for tax and criminal law, while the 'typical notions' are associated with the province of private law [5,77].

\section{The Pertinent Application of Law}

In the domain of statutory law, analogical reasoning can also be linked with a specific technique of composing canonical texts, namely the so-called "pertinent application of law".

In the text of a statute, in order to avoid repeating the same or very similar provisions, it is sometimes deliberately stated that the set of specific statutory provisions should also be applied to some other scope of circumstances despite these provisions literally not encompassing them. For example, it can thus be directed that the provisions that regulate the contract of the sale of goods are to be applied to the contract of the exchange of goods. As a result, the provisions primarily designated for one legal institution in fact regulate two legal institutions: one directly and one due to the statutory reference made to this aim. Such reference can be here to one or several statutory provisions, but equally it can encompass a larger group of such provisions or even concerns the whole statute. Interestingly, however, the provisions the reference is made to may be stated to have to be applied or to be applied pertinently (properly); in this second case, however, it is done without any further specification of what the pertinent/proper application stands for. As expounded in legal doctrine, such an application shall mean that all of the relevant differences and similarities that exist between the institutions to which these provisions apply directly and the institution to which these provisions apply only upon the reference should be taken into account. In consequence, in relation to the latter institution, particular provisions can then be applied without any modification, with some (they may concern a consequent as well as an antecedent and frequently be pretty obvious and slight, but sometimes they can also be of a fairly complex and sophisticated nature) [49,81] or even not applied at all. These three possibilities give sense to the phrase of "pertinent application" and differentiate it from direct (as they are) application of the provisions referred, which technique - as already mentioned - is also used in drafting legal acts $[4,6,11,30,49,81]$.

Because the results of "pertinent application" are dependent on the comparison of the nature (gist) of the involved institutions and the similarities and dissimilarities between them, analogical reasoning is said to be at work here. Korybski et al. comprehend it even in terms of analogia legis [47]. Moreover, the legislative decision that some institutions are to be regulated by the same or a similar set of statutory rules, one directly and one upon the reference, suggests that the Legislator considers them to be alike. In addition, it is notably that "pertinent application" does not entail the filling of a gap; this time the resort to similar statutory provision(s) is ordered by the statutory law itself $[47,49,81]$. It must, however, be intimated that not everyone sees in the "pertinent application of law" room for an analogical argument to be employed $[11,49]$.

\section{Argumentum a Fortiori}

As one more example of the employment of analogical reasoning in statutory law one may consider the so-called "argumentum a fortiori". In general this argument is regarded as having two forms. The first is called "argumentum a maiori ad minus" (from the greater to the smaller), while the second is called "argumentum a minori ad maius" (from the smaller to the greater). Within the "argumentum a maiori ad minus", a fortiori works in the way: "who may more, all the more so 
Page 7 of 10

may less", and concerns those statutory provisions that permit to do something, or alternatively in the way: "who is ordered more, all the more so, is ordered less", and then relates to the provisions that order something. "Argumentum a minori ad maius", in turn, runs as follows: "who is forbidden less is all the more so forbidden the more", and it pertains to those statutory provisions which prohibit to do something $[4,7,8,10,16,45,47,56]$. This is not, however, so easy as it may appears and in literature there are also advanced as for examples which are illusive in the sense that they only seemingly lead to the a fortiori conclusions $[16,22]$.

Indeed, this argument/mode of inference is occasionally perceived as a version of reasoning by analogy [82] or even as "an amplified reasoning by analogy" $[38,56]$. Inevitably, argument a fortiori and analogical reasoning have much in common. First, both are applied in configurations in which a legal gap (unprovided case) occurs. Second, the outcome of argumentum a fortiori - as with analogical conclusions - is dependent on evaluation (assessment). Third, both the a fortiori and analogy used in statutory law back themselves by reference to some valid statutory rule or rules [25,58]. Fourth, each of them may have examples/instances as their point of departure whose legal consequences are uncontested. Incidentally one may also consider enhancing (combining) argument by example by (with) argument a fortiori [22].

Additionally, Perelman maintains for instance that argumentum a fortiori - as analogy - bases upon the sprite of a statute [14]. Lechniak points out that the arguments: a fortiori and a simile overlap in that both require referring to the intention of Legislator [15]. Massimo et al. in turn, intimate that a fortiori as well as analogy could be defined as 'incomplete', i.e., since both of them have to be accompanied by others arguments in order for a legal decision can be made (each of these argument needs some "substantive criteria of evaluation" that are not provided by this argument itself) [44].

The difference between these two argumentative forms lies, however, in the sort of the similarity that has to obtain between cases being compared. That is, while reasoning a fortiori, one argues that the regulated and unregulated cases should be treated alike not because they merely sufficiently resemble each other, but because the unregulated case deserves the certain kind of treatment in a higher degree than the regulated case. In other words, it might be said that the unregulated case presents itself here as more similar to the regulated case than this case is to itself [4-6,8-10,12-19,38,53,55,56,78]. In a fortiori, the facts of an unprovoked case thus constitute not an equal but stronger support for ascribing to this case the legal consequence envisaged for the case which is provided for [82]. As a corollary, the need for maintaining the coherence within the legal system also calls here for assigning this legal consequence to an unprovoked case if compared with ordinary analogical legal reasoning [56].

Because of the need to compare "the relative strength of two sets of facts" or because of the ascertaining of a degree in which both cases, regulated and unregulated one, deserve such-and such treatment, an a fortiori inference is considered as a form of analogical thinking $[38,56,82]$. Parenthetically, it may be also noted that argumentum a fortiori inference is not exclusive to the province of statutory law, being employed in precedential law as well [82-84]. As Hage remarks, "if the old case was a suitable case for the decision that was actually taken in it, and the new case is just as suitable or even more suitable for such a decision, there is reason to take this decision in the new case too" [83], or as Alexander et al note, "if the facts of a new case provide support for the outcome reached in the precedent case that is stronger than the support provided by the facts of precedent case itself, then it follows, a fortiori, that the new court should reach a parallel result" [82].

\section{Analogia Iuris}

More mysterious and puzzling than analogia legis is its relative called: "analogia iuris" ("analogia juris"). Other names one may encounter to denote it are: law-analogy, legal-system analogy and however this one is less accurate - legal induction $[7,10,45,56]$. In German legal theory, analogia iuris is called "Rechtsanalogie" [41,52].

In general, analogia iuris is said to be based upon general principle(s) or idea(s)/value(s) $[4,6,7,10,11,17,18,30,41,44-46,49,51-53,56]$ "fundamental thought of legislator" [20], or even the very spirit (soul) of the law $[18,43,53]$ alias the legal order (system) comprehended as such [16,45]. As its basis, there a pack/set of statutory rules [10,41,49], a larger part of a statute or the whole one can also be used $[4,6,9,49,53]$.

Whether such a reasoning (argument/inference) as analogia iuris involves an analogical mode of thinking seems, however, to be an open question. It is sometimes even claimed that the very name: "analogia iuris" is in essence misleading and erroneous $[11,30,49]$. Hence a better term would be here: "free gap-filing", i.e., the filling of the gap with "due consideration to all the circumstances of the case (at hand)" [42], or "free creation of law" [42]. Be it a form of analogy or not - analogia iuris is commonly associated with axiology and the need for keeping coherence within the legal system. Notably, the general justification of using it and the main reason for employing it in a given case are deemed to stem from the axiological consistence which as such is supposed on the part of the rational Legislator [12,13,34,55]. Values or goals that are present/pursued in the legal system speak here for treating the unprovided case in the same or similar manner as the regulated case or cases $[10,12,13,18,19,34,54,55,78]$.

Incidentally, analogia iuris resting on the preferences of particular values on the part of the Legislator may also be linked with an argumentum a fortiori whose basis is the extent to which a given value is protected $[6,19,54,78]$.

Regardless of the above-mentioned terminological reservations, taking advantage of analogia iuris is allowed in civil law legal systems to an extent identical to analogia legis (statutory analogy), i.e., to liquidate a legal gap (especially extra or contra legem). However, there seems to be an order of preference established in the sense that analogia iuris can be used only when analogia legis has proved insufficient for making a legal decision in the case at hand $[4,6,10,44,45]$.

Incidentally, as a bow towards analogia iuris, one may also treat Dworkin's theory of the judge Hercules, a theory which assumes that legal decisions are to be delivered upon a coherent set of abstract general legal principles which justify all common law precedents (excluding those that are considered as mistakes) and statutory and constitutional provisions [85]. This theory is regarded as being founded upon analogical reasoning, for instance, by Raz and Maris. The former overtly states that "Dworkin's theory of adjudication is the most extreme case of total faith in analogical arguments" (i.e., in the sense that Dworkin "propounded a view according to which judges are obliged to solve all legal cases on the basis of a total analogy - to all the existing statutory and common law rules") [33]. The latter, in turn, discerns in the Dworkinian proposition something which 'can be labeled as reasoning by "super analogia iuris"' [51]. Interestingly, 
Lamond also hints - not without critical remarks - at an analogy that is based upon principles that underlie existing cases in the sense of justifying and explaining their legal outcomes [84]; Incidentally the very idea of reasoning from principle as well as Dworkinian theory have been severely criticized [82].

\section{Analogy in Legal Proof and Legal Fictions}

Undoubtedly, analogical reasoning can also be of use in the process of proving the facts of a case. As a good example, one may invoke the determination whether an alleged infringement of copyright took place through a comparison of the original item with the materials that are supposed to be its illegal copies. Contingent on the ascertained degree of the similarity between them, the question of infringement may be resolved: the greater the similarity, the more probable the illegal character of a copy would be [60].

Also fictions, i.e., legal concepts that are - at face value - unrealistic (false), are sometimes deemed to be a manifestation of analogy. Thus, for instance, an institution of adoption assumes a similarity between an adoptee and the siblings, mandating their equal treatment [77].

\section{Conclusions}

Analogical reasoning evidently has enormous scope for plausible applications in the domain of statutory law. This scope can be even likened - if not equated - to the ambit of the employment of analogy in the field of precedential law [88]. Not only is analogy used in statutory law in order to fill divergent kinds of gaps, but it can be also useful in resolving conflicts between statutory rules and clarifying the meaning of their wordings. It can also serve as a universal means by which one may apply particular statutory provisions in concrete cases. Such an omnipresence of analogical reasoning remains in statutory law, however, quite opaque and hidden - at least when referring to civil law countries. Due to the complex conceptual apparatus and premium that is traditionally placed on legal deduction and other kinds of quasilogical mental operations on general rules in these countries, an analogical pattern of inference must often be extracted from argumentative forms and notions that not necessary at first glance suggest its involvement. As it appears, its presence there may also remain sometimes more a psychological fact than something which is openly admitted in the theory and practice of law.

\section{Acknowledgement}

This article is connected with the research project the Author carried out in the United Kingdom as a guest researcher at Aberystwyth University as part of the Polish governmental programme: 'Mobilność Plus' ['Mobility Plus'].

\section{References}

1. Sunstein CR (1996) Legal reasoning and political conflict. Oxford university press, New York, USA.

2. MacCormick N (1978) Legal reasoning and legal theory. Clarendon press, Oxford, UK.

3. Bergholz G, Peczenik A (1997) Precedent in Sweden, In: Interpreting precedents: A comparative study. Ashgate/Dartmouth, Aldershot pp: 293-314.

4. Morawski L (2006) Principles of interpretation of the law ( $1^{\text {st }}$ edtn), TNOiK Home of Organizer, Torun, Poland.

5. Morawski L (2006) Introduction to jusrisprudence. ( $10^{\text {th }}$ edtn), TNOiK Home of Organizer, Torun, Poland.
6. Morawski L (2002) Interpretation in the opinions of courts: Commentary. TNOiK Home of Organizer, Torun, Poland.

7. Chauvin T, Stawecki T, Winczorek P (2012) Introduction to Jurisprudence. ( $7^{\text {th }}$ edtn), C.H. Beck publishers, Warsaw, Poland.

8. Nawrot O, Przybylski-Lewandowski F (2007) Legal inferences. In: Zajadło $\mathrm{J}$ (Editors) Lexicon of contemporary theory and philosophy of law. 100 of the basic concepts. C.H. Beck publishers, Warsaw, Poland pp: 344-348.

9. Mastalski R (2008) The application of tax law. Wolters Kluwer publishers, Warsaw, Poland.

10. Pulka Z (2008) Fundamentals of law: Basic notions of law and jurisprudence. Publishing scientific forum, Poznań, Poland.

11. Opałek K, Wróblewski J (1969) The issues of legal theory. State scientific publishers, Warsaw, Poland.

12. Wronkowska S, Ziembiński Z (1997) An outline of the theory of law. Ars boni et Aequi Publishers, Poznań, Poland.

13. Redelbach A, Wronkowska S, Ziembiński Z (1992) The outline of the theory of state and law. Scientific publishers PWN, Warsaw, Poland.

14. Perelman Ch (1984) Legal logic: The new rhetoric. State scientific publishers, Warsaw, Poland.

15. Lechniak M (2006) Elements of logic for lawyers. KUL publishers, Lublin, Poland.

16. Stelmach J (2003) Argumentative code for lawyers. Zakamycze publishers, Kraków, Poland.

17. Jabłońska-Bonca J (2008) Introduction to law. LexisNexis publishers, Warsaw, Poland.

18. Korybski A, Leszczyński L, Pieniążek A (2007) Introduction to jurisprudence. Maria Curie-Sklodowska University publishers, Lublin, Poland.

19. Ziembiński Z (1980) Fundamental problems of jurisprudence. PWN publishers, Warsaw, Poland.

20. Wolter W, Lipczyńska M (1980) Logic: Lecture for lawyers. (3 ${ }^{\text {rd }}$ edtn), State scientific publishers, Warsaw, Poland.

21. Nowacki J (2000) Analogy legis and legal justice. In: Valeat aequitas: Commemorative book offered to Rev. Prof Remigiusz Sobańskiemu (Editor: Pazdan M) University of Silesia publishers, Katowice, Poland pp: 321-324.

22. Perelman Ch (2004) Empire rhetoric: rhetoric and argumentation. PWN Publishers, Warsaw, Poland.

23. Lenoble J (1991) The function of analogy in law: Return to Kant and Wittgenstein. In: Legal knowledge and analogy. Fragments of legal epistemology, hermeneutics and linguistics (Editor: Nerhot P) Kluwer academic publishers, Dordrecht, Netherlands pp: 107-144.

24. Zaccaria G (1991) Analogy as legal reasoning - The hermeneutic foundation of the analogical procedure, In: Legal knowledge and analogy: Fragments of legal epistemology, hermeneutics and linguistics (Editor: Nerhot P). Kluwer academic publishers, Dordrecht, Netherlands pp: 42-70.

25. Wróblewski J (1992) The judicial application of law. Kluwer academic publisher, Dordrecht, Netherlands.

26. Nowacki J (1962) Conflicting norms and issue of gaps. Legal and Economic Studies 2: 49-62.

27. Nowacki J (1969) The concept of gaps contra legem. Scientific Papers of the University of Lodz 66: 3-15.

28. Nowacki J (1972) The so-called vertical "gaps" in the law. Scientific Papers of the University of Lodz 85: 55-63.

29. Nowacki J (1967) The so-called structural gaps in the law. Scientific Papers of the University of Lodz 51: 3-18.

30. Smoktunowicz E (1970) The analogy in administrative law. State scientific publishers, Warsaw, Poland.

31. Summers RS (1997) Precedent in the United States (New York State). In: Interpreting precedents: A comparative study (Editors: MacCormick N, Summers RS). Ashgate/Dartmouth, Aldershot, UK pp: 355-406.

32. MacCormick DN (2005) Rhetoric and the rule of law: A theory of legal reasoning. Oxford University Press, Oxford, UK. 
33. Raz J (1979) The authority of law: Essays on law and morality. Oxford University Press, Oxford, UK.

34. Municzewski A (2004) The rules of interpretation in the judicial activity of the Supreme Court. Publishing house of the University of Szczecin, Szczecin, Poland.

35. Koszowski M (2013) A few rare words about legal gaps. Archive for philosophy of law and social philosophy 1: 109-122.

36. Wróblewski J (1991) Statutory interpretation in Poland. In: Interpreting statutes: A comparative study (Editors: MacCormick DN, Summers RS). Ashgate/Dartmouth, Aldershot, UK pp: 257-309.

37. Nowacki J (1970) Gaps in the law: Ideology. Legal and economic studies 4: 29-52.

38. Peczenik A, Bergholz G (1991) Statutory interpretation in Sweden. In: Interpreting statutes. A comparative study (Editors: MacCormick DN, Summers RS). Ashgate/Dartmouth, Aldershot, UK pp: 311-358.

39. Bankowski Z, MacCormick DN (1991) Statutory interpretation in the United Kingdom. In: Interpreting statutes: A comparative study (Editors: MacCormick DN, Summers RS). Ashgate/Dartmouth, Aldershot, UK pp: 359-406.

40. Summers RS (1991) Statutory interpretation in the United States. In: Interpreting statutes: A comparative study (Editors: MacCormick DN, Summers RS), Ashgate/Dartmouth, Aldershot, UK pp: 407-459.

41. Alexy R, Dreier R (1991) Statutory interpretation in the Federal Republic of Germany. In: Interpreting statutes: A comparative study (Editors: MacCormick DN, Summers RS). Ashgate/Dartmouth, Aldershot, UK pp: 73-121.

42. Aarnio A (1991) Statutory interpretation in Finland. In: Interpreting statutes: A comparative study (Editors: MacCormick DN, Summers RS). Ashgate/Dartmouth, Aldershot, UK pp: 123-170.

43. Troper M, Grzegorczyk Ch, Gardies JL (1991) Statutory interpretation in France. In: Interpreting statutes: A comparative study (Editors: MacCormick DN, Summers RS). Ashgate/Dartmouth, Aldershot, UK pp: 171-212.

44. La Torre M, Pattaro E, Taruffo M (1991) Statutory interpretation in Italy, in: Interpreting statutes: A comparative study (Editors: MacCormick DN, Summers RS). Ashgate/Dartmouth, Aldershot, UK pp: 213-256.

45. Jamróz A (2011) Introduction to jurisprudence. ( $2^{\text {nd }}$ edtn), LexisNexis publishers, Warsaw, Poland.

46. Zuleta-Puceiro E (1991) Statutory interpretation in Argentina, In: Interpreting statutes: A comparative study (Editors: MacCormick $\mathrm{N}$, Summers RS). Ashgate/Dartmouth, Aldershot, UK pp: 29-71.

47. Korybski A, Grzonka L (2014) Knowledge of state and law: Outline of lecture. Wolters Kluwer publishers, Warsaw, Poland.

48. Nerhot P (1991) Legal knowledge and meaning (The example of legal analogy). In: Legal knowledge and analogy. Fragments of legal epistemology, hermeneutics and linguistics (editor: Nerhot P). Kluwer academic publishers, Dordrecht, Netherlands pp: 183-197.

49. Nowacki J (1966) Analogia legis. State scientific publishers, Warsaw, Poland.

50. Summers RS, Taruffo M (1991) Interpretation and comparative analysis In: Interpreting statutes: A comparative study (Editors: MacCormick DN, Summers RS). Ashgate/Dartmouth, Aldershot, UK pp: 461-510.

51. Maris CW (1991) Milking the meter - On analogy, universalizability and world views, In: Legal knowledge and analogy. Fragments of legal epistemology, hermeneutics and linguistics (Editor: Nerhot P) Kluwer academic publishers, Dordrecht, Netherlands pp: 71-106.

52. Holland J, Webb J (2010) Learning legal rules ( $7^{\text {th }}$ edtn) Oxford University Press, Oxford, UK.

53. Nowacki J, Tobor Z (2007) Introduction to jurisprudence. ( $3^{\text {rd }}$ edtn), Wolters Kluwer publishers, Warsaw, Poland.

54. Wronkowska S (2005) Basic concepts of law and jurisprudence. $\left(3^{\text {rd }}\right.$ edtn), Publishing company Ars Aequi et Boni, Poznań, Poland.

55. Leszczyński L (2004) Issues of theory of application of law: doctrine and jurisprudence thesis. Zakamycze publishers, Kraków, Poland.
56. Peczenik A (2009) On law and reason ( $2^{\text {nd }}$ edtn), Springer International Publishing, Switzerland.

57. Nowacki J (1962) The problem of law creative nature of the results of reasoning by analogy. Scientific Papers of the University of Lodz 62: 19-38.

58. Nowacki J (1969) Law making and "application" of the law by analogy and a fortiori. Legal and Economic Studies 3: 31-45.

59. Zeidler K (2007) Gap in the law. In: Encyclopedia of contemporary theory and philosophy of law. 100 of the basic concepts (Editor: Zajadło J) C.H. Beck publishers, Warsaw, Poland: 183-185.

60. Walton D (2008) Informal logic: A pragmatic approach (2 ${ }^{\text {nd }}$ edtn). Cambridge University Press, Cambridge, UK.

61. Cross R (1968) Precedent in English law ( $2^{\text {nd }}$ edtn). The Clarendon Press, Oxford, UK.

62. MacCormick DN, Summers RS (1991) Interpretation and justification. In: Interpreting statutes: A comparative study (Editors: MacCormick DN, Summers RS). Ashgate/Dartmouth, Aldershot, UK pp: 511-544.

63. Murray MD, DeSanctis CHH (2005) Legal research and writing. Foundation Press, CA, USA.

64. Schauer F (2009) Thinking like a lawyer: A new introduction to legal reasoning. Harvard University Press, Cambridge, UK.

65. Posner RA (2008) How judges think. Harvard University Press, Cambridge, UK.

66. Levi EH (1949) An introduction to legal reasoning. The University of Chicago press, Chicago, USA.

67. Braman E (2009) Law politics \& perception. How policy references influence legal reasoning. University of Virginia press, Charlottesville, USA.

68. Sunstein CR (1992-1993) Commentary on analogical reasoning. Harvard Law Review 106: 741-791.

69. Burton SJ (2007) An introduction to law and legal reasoning. ( $3^{\text {rd }}$ edtn), Wolters Kluwer publications, Austin, USA.

70. Brewer S (1995-1996) Exemplary reasoning: Semantics, pragmatics, and the rational force of legal argument by analogy. Harvard Law Review 109: 923-1028.

71. Weinreb LL (2005) Legal reason: The use of analogy in legal argument. Cambridge University press, Cambridge, UK.

72. Hart HLA (1994) The concept of law. (2 ${ }^{\text {nd }}$ edtn), Oxford University press, Oxford, UK.

73. Golding MP (2001) Legal reasoning. Broadview press, Peterborough, Canada.

74. Brożek B (2007) Rationality and discourse: Towards a normative model of applying law. A Wolters Kluwer business, Warsaw, Poland.

75. Gizbert-Studnicki T (1978) Lexical ambiguity in the interpretation of law. Printing of the Jagiellonian University in Krakow, Krakow, Poland.

76. Zieliński M (2006) Interpretation of the law: Principles, rules, guidelines. ( $3^{\text {rd }}$ edtn), LexisNexis publishers, Warsaw, Poland.

77. Kratochwil FV (1989) Rules, norms and decisions: On the conditions of practical and legal reasoning in international relations and domestic affairs. Cambridge University Press, Cambridge, UK.

78. Ziembiński Z (1990) Introduction to axiology for lawyers. Legal Publishing, Warsaw, Poland.

79. Kalisz A (2007) The interpretation and application of Community law. Wolters Kluwer publishers, Warsaw, Poland.

80. Hunter D (2001) Teaching and using analogy in law. Journal of Association Legal Writing Directors 2: 151-168.

81. Nowacki J (1964) Pertinent application of law. State and Law 3: 367-376.

82. Alexander L, Sherwin E (2008) Demystifying legal reasoning. Cambridge University Press, Cambridge, UK.

83. Hage J (2005) Studies in legal logic. Springer publishers, Dordrecht, Netherlands.

84. Lamond G (2006) Precedent and analogy in legal reasoning. In: The Stanford Encyclopedia of Philosophy, Stanford University, USA. 
Citation: Koszowski M (2017) Analogical Reasoning in Statutory Law. J Forensic Res 8: 1000372. doi:10.4172/2157-7145.1000372

Page 10 of 10

85. Dworkin R (1977) Taking rights seriously. Harvard University press, 87. Nowak L (1973) Legal interpretation: Study from the methodology of Cambridge, UK. jurisprudence. State scientific publishers, Warszawa.

86. Gizbert-Studnicki T (1988) Legal principles and rules. State and Law 3: $16-26$.

88. Koszowski M (2016) The scope of application of analogical reasoning in precedential law. Liverpool Law Review 1: 9-32. 